\title{
A PRESENÇA ANIMAL EM "SURDOS E CEGOS" E "AÇOUGUE", DE ASTRID CABRAL
}

\author{
Ana Paula Cantarelli ${ }^{1}$
}

Resumo: Este estudo visa discutir dois poemas de Astrid Cabral, "Surdos e cegos" e "Açougue", pertencentes ao livro Jaula (2006), a partir da forma como os eu-líricos se posicionam em relação ao abate e à comercialização de bovinos destinados à alimentação humana. Para tal, ele encontra-se dividido em duas partes. A primeira aborda o distanciamento adotado pelos homens frente aos demais animais sob um viés históricosociológico, empregando como fundamentação teórica obras de Montaigne (2006) e de Nietzsche (1998, 2007). A segunda propõe uma relação entre as discussões estabelecidas na primeira parte e o conteúdo dos poemas selecionados alicerçada em dois pontos: a existência de matadouros em nossa sociedade e a oposição razão X pathos. Para o desenvolvimento dessa parte, foram utilizados textos de Derrida (2002, 2003), Maciel (2016), Nunes (2011) e Giorgi (2011).

Palavras-chave: razão; pathos; poesia; animalidade; matadouros.

\begin{abstract}
This study aims to discuss two poems by Astrid Cabral, "Surdos e cegos" and "Açougue ", belonging to the book entitled Jaula (2006), starting from how the lyricals stand in relation to the breeding and slaughtering of cattle intended for human consumption. For this, it is divided into two parts. The first one deals with the distancing adopted by men towards other animals under a historical-sociological bias, employing as theoretical basis works by Montaigne (2006) and Nietzsche (1998, 2007). The second part proposes a relationship between the discussions in the first part and the content of the selected poems based on two points: the existence of slaughter houses in our society and the opposition of reason versus pathos. For the development of this part, texts of Derrida (2002, 2003), Maciel (2016), Nunes (2011) and Giorgi (2011) were appointed.
\end{abstract}

Keywords: reason; pathos; poetry; animality; slaughterhouses.

\section{CONSIDERAÇÕES INICIAIS}

A manauara Astrid Cabral possui uma expressiva produção literária, tendo já recebido diversos prêmios por sua escrita. Segundo Voigt (2018, p. 02), ela "é uma das mais longevas poetisas brasileiras", uma vez que "há mais de 50 anos vem publicando prosa e poesia". Em relação a sua trajetória, vale a pena destacar a atenção concedida por Cabral ao cenário natural, resultando em obras como, por exemplo, Jaula (2006), objeto de análise deste estudo. Nesse livro, composto por quarenta poemas, a fauna é posta em evidência. O termo “jaula”, empregado como título, aciona no imaginário do leitor situações nas quais os animais encontram-se aprisionados, separados dos humanos. Porém, o que Cabral realiza, em seus poemas, na verdade, é o movimento inverso: uma aproximação entre

\footnotetext{
${ }^{1}$ Professora do Curso de Letras-Espanhol e do Mestrado Acadêmico em Estudos Literários, ambos da Fundação Universidade Federal de Rondônia (UNIR). Atualmente, desenvolve seu Pós-Doutorado na Universidade Estadual de Campinas (Unicamp). E-mail: anapaula.cantarelli@gmail.com.
} 
humanos e animais, através de um processo de reconhecimento mútuo. Seus eu-líricos humanos passam a aceitar suas animalidades, constatando que entre eles e os demais animais há uma proximidade ("Enfim o reconheço/ íntimo de mim, meu próximo" - CABRAL, 2006, p. 29), uma amizade ("À medida que envelheço/ digo: o bicho é meu amigo" - CABRAL, 2006, p. 29) e um parentesco ("Então eu toco sem nojo/ o corpo da exótica irmã”-CABRAL, 2006, p. 53). Percebemos, com o passar do livro, que quem estava enjaulado era o homem que, a partir de seu orgulho, arrogância e insensibilidade, qualificou a si próprio como superior, afastando-se dos demais animais e, consequentemente, da natureza. Há, nos poemas, a promoção do reconhecimento da alteridade animal através da discussão sobre a forma como o humano se relaciona com esses outros seres, os quais, ao mesmo tempo em que se configuram como uma outridade radical, também, compartilham com ele o ato de estar no mundo e tudo o que isso implica.

Dentre os poemas de Jaula, selecionei dois para abordar neste estudo: "Surdos e cegos" e "Açougue". Ambos tocam em um ponto controverso socialmente: a criação de animais para a alimentação humana. Com imagens eivadas de sangue, os eu-líricos versam sobre a forma como os animais destinados ao consumo são mortos e comercializados, sendo esse o centro das discussões que quero propor. Inicialmente, tratarei de forma breve, a partir de aspectos histórico-sociológicos, nosso distanciamento dos demais animais. Acontecimentos como o surgimento do cristianismo e o ingresso na Modernidade serão pontuados como marcos que interferiram, não apenas em nossa organização social, mas também em nossas condutas frente aos animais. Para tal, utilizarei obras de autores como Friedrich Nietzsche e Michel de Montaigne que discorrem sobre como a religião e a razão filosófica ocidentais moldaram nosso comportamento frente aos animais.

A seguir, quero propor uma relação entre o conteúdo dos poemas selecionados e o distanciamento entre homens e animais promovido pelo cristianismo e a racionalidade humana a partir de dois pontos. O primeiro diz respeito à existência de matadouros em nossa sociedade. Lugares destinados ao abate de animais, normalmente, localizados longe das áreas residenciais, ocultos aos olhos e ouvidos da população, mas que, no entanto, foram colocados em evidência por Astrid Cabral. O segundo ponto relaciona-se com a oposição razão X pathos e a limitação da filosofia e da ciência ocidentais em tratar do reconhecimento e da sondagem da alteridade animal, cabendo à literatura tal função. Para desenvolver esse ponto, destacarei não apenas os poemas de Cabral, mas também, de modo paralelo, a obra A vida dos animais, de J.M. Coetzee, a partir das falas da protagonista Elizabeth Costello, quem compara filosofia e literatura frente à tarefa de percepção da alteridade animal. Tal 
personagem traz um interessante discurso sobre a questão dos matadouros, chegando a igualá-los aos campos de concentração existentes durante o Terceiro Reich - o que nos permite usar suas falas também para desenvolver o primeiro ponto. Como referencial teórico para embasar essa parte do estudo, recorrerei a textos de pesquisadores que têm se dedicado a abordar as relações entre humanos e animais, sejam elas no âmbito literário ou não, como, Jacques Derrida, Maria Esther Maciel, Benedito Nunes e Gabriel Giorgi. Ao final, espero conseguir apresentar algumas considerações sobre como Cabral tem se posicionado literariamente frente à forma como lidamos com a vida e a morte dos animais, esboçando alguns possíveis itinerários que nos permitam desvelar criticamente nossas práticas sociais em um processo de reconhecimento da alteridade animal.

\section{QUANDO DEIXAMOS DE SER ANIMAIS? COMO VOLTAMOS A SÊ-LO?}

A separação entre humanos e animais, inicialmente, foi promovida pelo cristianismo, o qual relacionou estes com o pecado, difundindo a ideia de que o homem, para andar pelo caminho da igreja e alcançar o paraíso, necessitava denegar sua animalidade. Desde as origens do cristianismo, há uma separação entre corpo e alma. O primeiro, material e sujeito à morte, era associado à vida terrena. A segunda, imortal, era o que se desejava salvar e elevar ao céu. Quem almejasse a salvação da alma deveria rejeitar os desejos do corpo, pois este representava o instinto, a carne, a matéria, estando próximo ao animal, e, por conseguinte, ao terrenal, distanciando o homem de Deus, do sublime, do elevado. De acordo com Benedito Nunes (2011, p. 14), com o cristianismo, "passamos, então, a ver o animal simbolizando o irascível dos sentimentos e a bruteza dos instintos. O animal habitava o homem e dentro dele rugia, porém como algo que lhe era estranho".

O filósofo alemão Friedrich Nietzsche criticou duramente, em várias de suas obras, a forma como o cristianismo promoveu a negação da animalidade humana. Em Para além do bem e do mal, ele reprovou os ensinamentos cristãos, qualificando-os como extremamente negativos para a sociedade: "O cristianismo foi, até hoje, a mais funesta das presunções" (NIETZSCHE, 2007a, p. 87). Nessa obra, Nietzsche afirma que tal doutrina religiosa colocou de cabeça para baixo todos os valores humanos: 
Quebrar os fortes, debilitar as grandes esperanças, tornar suspeita a felicidade da beleza, converter tudo o que é soberano, viril, conquistador e dominador, todos os instintos próprios do tipo "homem" mais elevado e mais bem conseguido, em incerteza, tormento de consciência, autodestruição, inverter mesmo todo o amor às coisas terrenas e do domínio da terra em ódio contra a terra e o que é terreno - eis a tarefa que a Igreja se impôs e que teve de impor-se, até que, na sua perspectiva "desmundanização", "dessexualização" e "homem superior" se fundiram enfim num sentimento único. (NIETZSCHE, 2007a, p. 87)

De acordo com os escritos nietzschianos, o cristianismo propôs uma forma de existência que se distancia do real, negando alguns comportamentos que são próprios do homem. Esse distanciamento entre o que é apregoado religiosamente e a realidade provinda das experiencias e emoções humanas foi criticado pelo filósofo, também, em $O$ anticristo, obra na qual ele defende que os ideais da igreja são antinaturais, constituindo-se como uma ficção, a qual mostra-se hostil à vida e, por conseguinte, a tudo que é humano, animal e material:

Nem a moral nem a religião, no cristianismo, têm algum ponto de contato com a realidade. Nada senão causas imaginárias ("Deus", "alma", "Eu", "livre-arbítrio" ou também "cativo"); nada senão efeitos imaginários ("pecado", "salvação", "graça", "castigo", "perdão dos pecados"). Um comércio entre seres imaginários ("Deus", "espíritos", "almas"). (...) Somente depois de inventado o conceito de "natureza", em oposição a "Deus", "natural" teve de ser igual a "reprovável" - todo esse mundo fictício tem raízes no ódio ao natural (-a realidade!-), é a expressão de um profundo mal-estar com o real... (NIETZSCHE, 2007b, p. 20-21).

Seguir os preceitos do cristianismo, para Nietzsche, torna o homem doente, uma vez que o desconecta de seu passado animal, de seus instintos natos, rompendo-lhe o vínculo com a natureza da qual ele faz parte: o homem doente de si mesmo foi consequência "de uma violenta separação do seu passado animal (...), resultado de uma declaração de guerra aos velhos instintos nos quais até então se baseava sua força, seu prazer e o temor que inspirava" (NIETZSCHE, 1998, p. 73). Ao reconhecer nos preceitos do cristianismo as origens da separação entre homens e animais, é possível perceber que reside aí um dos cernes que justificam o aprisionamento e os maus-tratos para com estes. $\mathrm{O}$ animal, ao tornar-se símbolo do pecado, sendo vinculado à terra, ao que é baixo, em oposição ao céu, ao paraíso e à salvação almejados pelo homem, passou a constituir-se como um ser inferior que representava tudo o que a religião rejeitava. Tal forma de pensamento estabeleceu uma relação entre os humanos e os demais animais que legitimava a agressão, a captura e a morte destes, uma vez que, por não terem alma 
e por serem associados ao pecado, qualquer coisa que lhes fosse imputada era justificada religiosamente.

Como intensificadoras dessa separação encontramos a filosofia e a ciência ocidentais. De acordo com Maria Esther Maciel (2016, p. 16), “a cisão entre homem e animal, humanidade e animalidade - tal como ela se institui na sociedade ocidental - teve seu ponto crucial na Era Moderna, mais especificamente a partir do século 18, com o triunfo do pensamento cartesiano". O que já havia sido estabelecido religiosamente foi referendado através do pensamento científico e filosófico ocidental, promovendo separações que cada vez mais distanciaram os humanos dos demais animais: “visto como máquina, um mero corpo automatizado e sem alma, o animal passou, desde então, a ser investigado com base em critérios científicos bem definidos" (MACIEL, 2016, p. 16).

Com o início da Era Moderna, a racionalidade humana foi erigida como um dos eixos estruturadores da organização social. O ensaísta e crítico literário mexicano Octavio Paz, em seu livro Os filhos do barro, ao abordar a racionalidade humana na Modernidade, declarou que "a razão surgiu como um princípio suficiente: idêntica a si mesma, nada a fundamenta a não ser ela própria e, portanto, é a base do mundo" (PAZ, 1984, p. 46). Segundo ele, a sociedade moderna buscou explicar o mundo e seus mistérios - antes ofício religioso - cientificamente, com o intento de alargar as margens de segurança dos indivíduos, convertendo a racionalidade em uma faculdade que dá acesso aos segredos do universo, capaz de organizar e regular a vida pública, ocupando uma posição inquestionável.

Esse lugar central concedido à razão humana fez com que outras formas de conceber o mundo fossem consideradas inferiores. Como resultado disso, embora o homem reconheça-se cientificamente como um animal, ele adiciona a esse substantivo o termo racional como um diferenciador, autoatribuindo-se um lugar de destaque a partir do qual ele julga e decide sobre os demais animais: sem compartilhar do mesmo tipo de racionalidade, estes são tratados como inferiores. Assim, os humanos apossam-se de seus corpos, de suas vidas, controlando suas liberdades, sua alimentação, suas formas de reprodução e, inclusive, seus nascimentos e mortes.

O filósofo francês Michel de Montaigne, em seu texto “Apologia de Raymond Sebond”, que integra o Livro II de Os Ensaios, publicado em 1580, questionou a maneira como a racionalidade humana foi empregada enquanto critério diferenciador entre os humanos e os demais animais. Desde o princípio de seu texto, Montaigne destaca que os humanos pouco conhecem sobre a forma como os animais interagem entre eles, como se organizam, quais seus hábitos, etc. Entretanto, a partir da escolha da racionalidade, capacidade esta da qual apenas os seres humanos são dotados, eles atribuem a si 
próprios uma supremacia, outorgando aos demais animais características físicas, emocionais e intelectuais que lhes julgam adequadas:

\begin{abstract}
A presunção é a nossa doença natural e original. A mais calamitosa e frágil de todas as criaturas é o homem e ao mesmo tempo a mais orgulhosa. Ele se sente e se vê instalado aqui, em meio ao lodo e ao esterco do mundo, amarrado e pregado à parte pior, mais morta e infecta do universo, do pavimento mais baixo da casa e mais afastado da abóbada celeste, com os animais da pior das três condições²; e pela imaginação vai se implantando acima do círculo da lua e trazendo o céu para baixo de seus pés. É por vaidade dessa mesma imaginação que ele se iguala a Deus, que se atribui as características divinas, que seleciona a si mesmo e se separa da multidão das outras criaturas, divide em grupo os animais seus confrades e companheiros e distribui-lhes a porção de faculdades e de forças que bem lhe parece. Como conhece ele, por obra da inteligência, os movimentos internos e secretos dos animais? Por qual comparação entre eles e nós conclui sobre a estupidez que lhes atribui? (MONTAIGNE, 2006, p.181).
\end{abstract}

Com interrogações como as presentes ao final dessa citação, o filósofo assume uma postura de recusa em considerar a razão humana como soberana, fazendo, na verdade, o movimento inverso: a razão torna os homens arrogantes, impedindo-lhes de aprender através da observação sobre e com os demais animais. Montaigne, ao longo de seu ensaio, propõe uma outra forma de olhar para os animais: ele tenta demonstrar que mesmo os atributos que são tidos como exclusivos do homem (linguagem, habilidades arquitetônicas, organização social, música, conhecimentos matemáticos, astronomia, etc.) podem ser encontrados também em outros seres (e de forma superior em alguns casos: "Reconhecemos suficientemente, na maioria de suas obras, quanta superioridade os animais têm sobre nós e o quanto nossa arte é fraca em imitá-los" - MONTAIGNE, 2006, p. 185). O filósofo enfatiza as limitações do conhecimento racional, tornando infundada nossa pretensa superioridade: "Devemos observar a paridade que existe entre nós. Temos um conhecimento mediano do seu senso; os animais também o têm do nosso, mais ou menos na mesma medida. Eles nos acarinham, ameaçam-nos e solicitam-nos; e nós a eles" (MONTAIGNE, 2006, p. 182).

Se a religião, a filosofia e a ciência promoveram e solidificaram fronteiras entre humanos e animais, qual o caminho para a realização de uma aproximação? A resposta parece estar na literatura. De acordo com Maciel (2016, p. 14), "no que tange à literatura, sabe-se que as tentativas de sondagem da alteridade animal nunca deixaram de instigar a imaginação e a escrita de poetas e escritores de diferentes épocas e procedências". São inúmeros os escritores que, ao longo do tempo, se dedicaram a

\footnotetext{
${ }^{2}$ As três condições às quais Montaigne se refere são: animais aéreos, aquáticos e terrestres.
} 
abordar a relação entre homens e animais, dentre os quais podemos citar, no cenário internacional, Franz Kafka, Rainer Rilke, Lewis Carroll, Jorge Luis Borges e J. M. Coetzee, por exemplo; e, no cenário nacional, Guimarães Rosa, Clarice Lispector, Carlos Drummond de Andrade, João Alphonsus e Astrid Cabral. Dentre os mencionados, destaco de forma especial J. M. Coetzee que, em A vida dos animais, criou a personagem Elizabeth Costello $^{3}$ a qual defende a soberania da literatura sobre a filosofia para abordar as relações entre humanos e animais. Costello, ao longo da obra, apresenta uma oposição entre filosofia e literatura. A primeira, atrelada à razão, é atacada diretamente pela personagem. Segundo ela, a razão filosófica caracteriza-se pela exclusão do pathos (da paixão, da emoção, do sentir) e dos saberes que não podem ser racionalizáveis. Devido a isso, essa forma de razão é percebida como insuficiente pela personagem para julgar a relação entre homens e animais: a razão "não é a essência do universo, nem a essência de Deus. Ao contrário, e de forma bem questionável, a razão parece ser a essência do pensamento humano; pior ainda, a essência de apenas uma tendência do pensamento humano" (COETZEE, 2002, p. 29). A literatura, por sua vez, tem a capacidade de promover, através da sensibilidade, o valor ético, possibilitando ao poeta e aos leitores a percepção de si e de outros seres além da razão (o ser-no-mundo). Conforme Costello, através da literatura é possível despertar a simpatia, o reconhecimento do outro, criando uma oportunidade para pensar a existência de um ser que difere de mim.

Praticamente no mesmo período em que J. M. Coetzee escrevia os textos que deram origem ao A vida dos animais, o filósofo franco-argelino Jacques Derrida, preparava a palestra que resultou em $O$ animal que logo $\mathrm{sou}^{4}$, obra na qual questiona as dicotomias estabelecidas pelo pensamento racional ocidental entre os humanos e os demais animais apontando para a potencialidade da literatura para “passar as fronteiras entre o homem e o animal” (DERRIDA, 2002, p. 14). Nessa obra, Derrida narra um encontro com seu próprio gato, durante o qual o filósofo nu sentiu-se envergonhado de sua situação frente ao animal, sentimento esse que o levou a refletir sobre a insuficiência da racionalidade no processo de encontro com esse outro extremo: o animal.

Além da capacidade de operar através do pathos na promoção do reconhecimento da alteridade animal, a literatura dispõe de um importante recurso para romper das fronteiras erigidas

\footnotetext{
${ }^{3}$ Elizabeth Costello pode ser considerada como um alter ego de Coetzee uma vez que o autor, ao participar das Tanner Lectures, na Universidade de Princeton, surpreendeu sua plateia com a apresentação de duas narrativas ("Os filósofos e os animais" e "Os poetas e os animais" - os quais deram origem à A vida dos animais) ao invés de propor ensaios filosóficos. A personagem principal dos textos era Elizabeth Costello que, da mesma forma que Coetzee, era uma romancista vivendo na Austrália e que fora aos Estados Unidos devido a um convite para ministrar duas palestras em uma universidade.

${ }^{4}$ J. M. Coetzee participou das Tanner Lectures em 1997-8. No ano de 1997, ocorreu o terceiro colóquio de Cerisy, tendo a obra de Jacques Derrida como tema. Durante o evento, Derrida proferiu uma aula a qual deu origem à obra $O$ animal que logo sou.
} 
historicamente: a imaginação. Ao não compartilharmos uma linguagem comum com os animais, só nos resta a possibilidade de pensar esse outro ser, criando, através da imaginação, um encontro entre os mundos humano e não-humano. A construção desse encontro, literariamente, permite-nos acessar uma forma de vida, uma construção sobre o mundo e uma atuação que seriam impossíveis através da razão filosófica. A literatura, arte do fingimento, como apregoou Fernando Pessoa, abre a porta não apenas para que nos imaginemos em contato com os demais animais, mas também para que nos imaginemos como eles, possibilitando uma reconexão. Entretanto, como aponta Maciel (2016, p. 47), mesmo e sempre que "falhe a tal experiência de traduzir esse 'outro mais outro que qualquer outro', que está fora e dentro de nós mesmos, a poesia deixa sempre um resto, um rastro de saber sobre ele", configurando-se, assim, como uma possibilidade de aprendizado.

\section{CONSIDERAÇÕES SOBRE A OPOSIÇÃO RAZÃO X PATHOS EM "SURDOS E CEGOS" E "AÇOUGUE"}

"Surdos e Cegos" é um poema composto por apenas uma estrofe contendo treze versos, nos quais o eu-lírico faz uma crítica ao fato de os homens mostrarem-se indiferentes ao sofrimento e à morte de bois destinados ao consumo. Desde os primeiros versos a impassibilidade humana é mencionada: "Enquanto distraídos/ mastigam sangrentos bifes/ entre submissas cebolas/ comentam o absurdo/ da violência ao cubo" (CABRAL, 2006, p. 57). No fragmento citado, o termo "distraídos" denota que os homens comem os bifes sem atentar para sua origem, desconsiderando as condições implicadas na produção da carne que está em seus pratos. Já o adjetivo “sangrentos" pode ser percebido como uma referência à violência cometida contra o animal, cuja carne é consumida. Tal violência é ignorada pelos interlocutores ou considerada de menor relevância, uma vez que o que os aterra é a violência existente na sociedade resultante de conflitos entre os próprios homens ${ }^{5}$. A vida animal, nesse contexto, é posta em segundo plano.

Nos versos seguintes, o eu-lírico aborda a surdez frente ao sofrimento animal: "E homens surdos/ não ouvem o berro do boi/ conduzido ao curro" (CABRAL, 2006, p. 57). Não ouvir, no trecho

\footnotetext{
${ }^{5}$ Poderíamos pensar a existência de uma relação entre a violência humana mencionada no poema e a violência contra os animais ou que a recorrência de uma literatura sobre a violência contra os animais seja um reflexo da violência entre humanos, mas não há pesquisas que referendem isso. De modo que, neste estudo, consideraremos essas categorias como separadas entre si.
} 
citado, não está vinculado a uma impossibilidade física, mas sim a uma surdez voluntária, resultante da indiferença, na qual o berro de dor e de medo do animal é desconsiderado. Essa insensibilidade ao sofrimento está atrelada à forma como o animal é visto em nossa cultura, ao espaço que lhe concedemos. Ao tratar o animal como um ser sem alma e desprovido de raciocínio lógico, opta-se por ignorar o que este sente, desatentando, inclusive, para o fato de ele ser um ser vivente. Descartes (2001), por exemplo, em sua teoria mecanicista, considerava que o animal era o mais estranho em relação ao homem, sendo um grande outro, uma vez que era um corpo sem alma, um mero mecanismo.

Nos versos citados do poema de Cabral, também podemos associar a surdez frente aos berros dos bois ao fato de os abatedouros se localizarem, normalmente, distante das zonas residenciais, com o intuito de poupar os humanos da morte de outros seres. Gabriel Giorgi (2011, p. 203), no ensaio “A vida imprópria. Histórias de matadouros", relata que "um matadouro é uma zona separada, alheia, demarcada em relação à comunidade - onde a morte dos animais para produzir carne se coloca à distância da vida social-". Somado a esse distanciamento entre os matadouros e as residências está a forma como a carne chega aos supermercados e açougues. Ao ser fragmentada para facilitar a comercialização, ela perde sua identidade com o animal do qual se originou, dificultando a associação entre eles. Esses procedimentos afastam os homens do reconhecimento da vida e da morte de outros seres.

Os últimos versos do poema fazem uma referência à cegueira humana frente à morte animal: "E homens cegos/ não veem o sangue vivo/ do boi mungido quente/ no vaivém de mandíbulas/ entre verdugos dentes" (CABRAL, 2006, p. 57). O trecho citado retoma o sangue já presente ao início do poema, intensificando-o. $\mathrm{O}$ fato dos humanos, que se alimentam do boi, não terem presenciado a morte animal reforça o distanciamento entre os matadouros e a sociedade, a qual não vincula a carne consumida nem com a violência nem com o processo de morte do animal. Assim, enquanto os homens questionam a violência absurda que ocorre socialmente entre eles, mostram-se surdos e cegos à imputada aos demais animais.

O poema "Açougue" encontra-se, no livro, logo na sequência de "Surdos e cegos". É possível ler os dois de forma complementar, uma vez que em "Surdos e cegos" há referências ao processo de morte dos bois, enquanto em "Açougue” há menção à comercialização da carne desses animais. Com apenas uma estrofe contendo trinta versos, o título ("Açougue”) antecipa o conteúdo do texto. Dentro de um açougue, o eu-lírico descreve o que vê: “Os olhos de vidro não veem/ o que os verdadeiros já viram./ Ali a cabeça decepada/ insiste em máscara de vida./ O embuste fincado à parede/ lembra o abate dia após dia" (CABRAL, 2006, p. 58). A menção de uma cabeça empregada como decoração não causa estranheza no local onde se encontra. Exibida como ornamento, sua presença auxilia na 
constituição e apresentação do ambiente de comercialização de animais mortos: "Chairas cutelos facas cumprem/ no cepo o esquartejo do boi/ varejo dos membros em talho" (CABRAL, 2006, p. 58).

Ao longo do poema, o eu-lírico refere-se ao animal que, pela manhã, vivo, estava no pasto, e, ao ser morto, passou a configurar-se apenas como partes a serem comercializadas, mencionando cortes, frações, quantidades de músculos, fibras e gordura. Há a transformação de um ser em fragmentos a serem vendidos:

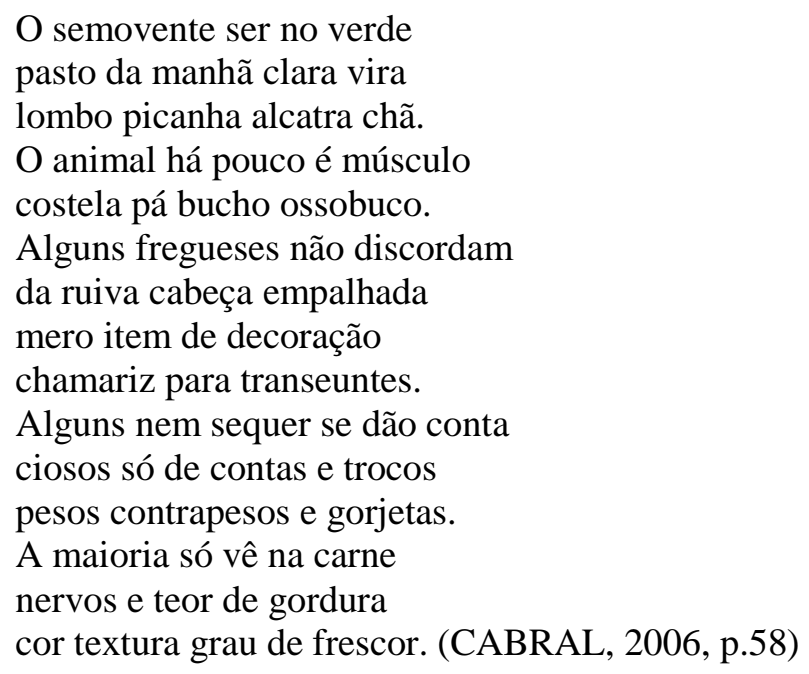

Essa forma de lidar com a carne dialoga com a surdez e a cegueira que acometem os sujeitos do poema anteriormente apresentado. Os eu-líricos apontam para a existência de uma dissociação entre a carne que é comercializada e consumida e o ser vivo da qual ela provém. O animal é exposto em sua vulnerabilidade, morto, seccionado, vendido, em uma racionalidade econômica que o objetifica, pesando-o, medindo-o, tornando-o uma mercadoria a mais. Os versos de Cabral referem-se com horror a esse processo. Porém, os consumidores não se incomodam com tal comércio, na verdade, veem-no como normal, ocupados entre contas, pagamentos e trocos. O eu-lírico de "Açougue" menciona o fato de muitos clientes sequer perceberem a existência de uma cabeça bovina decepada e empalhada fixada na parede (“Alguns nem sequer se dão conta”). Como um símbolo da morte que dia após dia se apresenta no açougue, à cabeça com olhos de vidros só resta observar o comércio das partes de outros animais. A vida animal é algo que pode ser comprado. O corpo animal é apropriável, comercializável: um corpo que pertence a alguém enquanto vivo e cujos fragmentos pertencerão a outros depois de morto. Nessa perspectiva, o animal sequer é dono de seu próprio corpo, o qual pode ser visto como um espaço de exploração e subjugação. 
Nos versos finais, o eu-lírico questiona sobre a forma como ocorre a matança e o consumo de carne: “A mim corta a afiada pergunta:/ que fome tão feroz é essa/ capaz de gerar o massacre/ de mansos bois, tenras vitelas?/ Que fome essa cujo repasto/ implica o brutal holocausto?” (CABRAL, 2006, p. 58-59). A associação entre a vitimização animal e a vitimização humana figura em textos desde muito tempo, estando presente em ensaios como, por exemplo, "Apologia de Reymond Sebond", de Montaigne, já citado aqui, no qual o filósofo relaciona a escravização de humanos e de animais. No entanto, a analogia entre o Holocausto e a matança de animais pode causar desconforto nos leitores uma vez que relaciona um dos mais brutais genocídios da Era Moderna ao processo de abate e consumo de bovinos. Tal correspondência fez parte, também, da fala da personagem de Coetzee, Elizabeth Costello, a quem recorro no intuito de explorar tal associação:

Vou falar abertamente: estamos cercados por uma empresa de degradação, crueldade e morte que rivaliza com qualquer coisa que o Terceiro Reich tenha sido capaz de fazer, que na verdade supera o que ele fez, porque em nosso caso trata-se de uma empresa interminável, que se autorreproduz, trazendo incessantemente ao mundo coelhos, ratos, aves e gado com propósito de matá-los. (COETZEE, 2002, p.26-27)

De acordo com Costello, em $A$ vida dos animais, as pessoas que viviam nas proximidades dos campos de concentração, onde os judeus foram torturados e assassinados, afirmaram não ter conhecimento sobre o que acontecia nesses lugares, apesar de serem capazes de imaginar. Embora tenham dito que podiam ter sabido, elas alegaram que não podiam se permitir saber para se preservarem. Essa cegueira e essa surdez (in)voluntárias, de acordo com a protagonista de Coetzee, é recusada por nós, tendo em vista a sua insuficiência como justificativa frente aos horrores cometidos nos campos de concentração.

Elizabeth Costello realiza uma associação entre o ato de preferir não saber o que o Terceiro Reich fazia com os judeus e o desconhecimento voluntário sobre a criação e o abate de animais para consumo. Segundo ela, os animais destinados a tornarem-se alimento são tratados como objetos dos quais dispomos sem considerar seu sofrimento: preferimos ignorar a forma como o pedaço de carne que compramos nos açougues e supermercados constituía um outro ser, criado sob condições que consideraríamos, normalmente, torturantes se fossem aplicadas a humanos, da mesma forma que os moradores ao redor dos campos de concentração preferiam não saber do sofrimento dos que lá estavam. O assassinato de humanos e o abate de animais é colocado por Costello no mesmo nível dentro da obra. Outros personagens esboçam argumentos contra esse tipo de associação, demonstrando sua indignação ao ter a vida de seres humanos comparada com a de animais. Por que ocorre esse tipo de revolta? A resposta da protagonista de Coetzee é simples: porque escolhemos a razão como centro de 
nossa sociedade e, ao considerarmos os animais como seres irracionais, os percebemos como inferiores, dispondo de suas vidas e controlando suas existências. Por isso, comparar a vida humana com a vida animal é algo que, racionalmente, mostra-se inadequado.

Descartes (2001) defendia que os animais existiam no mundo com a finalidade de servir ao homem, fosse como instrumento de trabalho, fonte de alimento ou fonte de lucro. Perceber o animal como um ser inferior ao humano está atrelado a um sentimento de ódio, de acordo com Benedito Nunes (2011, p. 15-16): “O trabalho deles é reproduzir-se para nós. Até seu sexo transforma-se em uma forma de trabalho. Não os odiamos mais porque nem sequer são dignos do nosso ódio. Nós os vemos com desprezo". O que odiamos e desprezamos não merece nossa consideração e, por conseguinte, não é passível de respeito. O desprezo e o ódio direcionado aos animais surgem, historicamente, atrelados aos princípios do cristianismo e da razão filosófica ocidentais, os quais ordenaram o lugar dos humanos e dos animais em nossa cultura, ditando a separação dos corpos e as formas de explorações. O cristianismo, ao associar o animal ao impuro, à terra, ao pecado e ao inferno, induziu o homem a renegar seus instintos, sua animalidade. Ao fazer isso, promoveu rejeição e ódio àquilo que afastava o homem do paraíso. Enquanto, a sociedade moderna, ao erigir a razão como seu fundamento, viu com desdém aqueles que não a possuíam. Assim, o ódio e o desprezo mencionados por Nunes, foram inculcados socialmente, gerando uma surdez e uma cegueira voluntárias frente ao destino dos animais. Giorgi, ao discorrer sobre a morte de animais em matadouros, nos faz pensar que a crueldade envolvida no processo, possivelmente, está atrelada não só à forma como esses seres são percebidos, mas, também, a uma necessidade constante de reiterar a superioridade outorgada pelos homens a si próprios:

A morte animal emerge como um mecanismo essencial, constitutivo de definir, de certo modo, o humano como hierarquia normativa e como superioridade ontológica: para produzir a exceção em relação às outras criaturas viventes, um animal, ou o animal, tem de morrer. No entanto, além disso, tem de morrer de uma morte irreconhecível, insignificante, sem autopercepção, sem autoconsciência, uma morte que desconhece a si mesma e que, portanto, equivale, para muitos, a uma morte sem morte. (GIORGI, 2011, p. 201)

Mas, se a violência contra os animais é algo que a sociedade prefere ignorar, por que Astrid Cabral fez disso matéria para seus poemas? Por que a autora optou por dar visibilidade e audibilidade frente ao que, pactualmente, a sociedade escolheu assumir uma surdez e uma cegueira voluntárias? A resposta, a meu ver, está no intento de abordar esse outro ser, diferente do homem, através de um movimento de reconhecimento e de aceitação, promovendo um processo de questionamento a partir de sentidos estéticos, históricos e políticos, o que só poderia ser feito literariamente. De acordo com 
Maciel (2016, p. 18), desde as últimas décadas do século XX e da primeira do século XXI, o campo artístico, de forma geral, tem produzido manifestações culturais destinadas a abordar as relações entre os homens e os demais animais, as quais tem sido "reconfiguradas a partir de outros enfoques, advindos de uma nova relação dos escritores e artistas não apenas com os animais, mas também com as conjunções/disjunções entre humanidade e animalidade". A literatura, ao aproximar humanos e animais, tateia a recuperação de uma conexão, há muito perdida, em um intento de acessar o outro, tornando-o próximo, através da escrita. Sobre essa sondagem da alteridade animal promovida pela literatura, Derrida (2002, p. 22) defendia que "o pensamento do animal, se pensamento houver, cabe à poesia”, visto que esta alcança algo além da razão: o sentimento.

O pensamento filosófico racional tem se mostrado inapto para descrever o que se sente frente a um outro ser, uma criatura diferente de mim, mas que ocupa o mesmo espaço, que habita a mesma existência, que está viva, repleta de experiências de interação com o mundo, cheia de sensações. Ao racionalizar a percepção do animal, nos deparamos com uma série de limitações que impossibilitam a sua apreensão: “O que sabemos sobre eles é um índice de nosso poder, e assim é um índice que nos separa deles. Quando mais julgamos saber, mais distantes eles ficam” (BERGER, 2003, 22).

Em A vida dos animais, Elizabeth Costello, ao tratar da literatura como possibilidade de apreensão do animal, emprega os poemas "A pantera", de Rilke; “O jaguar" e "Um segundo olhar para o jaguar", de Ted Hughes, os quais exploram a subjetividade animal, com o intuito de argumentar que a arte, em oposição ao discurso filosófico, desperta, através da sensibilidade, o valor ético, fazendo com que o poeta perceba o ser além da razão (o ser-no-mundo). A literatura teria, então, uma função ética: através do pathos, ou melhor, do simpathos (compaixão, empatia) e da imaginação promove o reconhecimento e a aceitação do outro e, nesse processo, também de si mesmo. Segundo Costello, a literatura é capaz de abrir nosso coração e de despertar nossa empatia pelo outro, ao contrário do discurso racional que bloqueia os sentimentos. A literatura outorga-se a capacidade de imaginar o outro, mesmo que este não compartilhe da mesma forma física ou da mesma linguagem, constituindose em uma fonte de sondagem.

Astrid Cabral, ao aproximar-se dos animais através da literatura, promoveu um espaço para repensar o lugar a eles concedido socialmente, dando visibilidade ao que a razão desconsidera. Os bois em "Surdos e cegos" e em “Açougue" são os outros extemos, sem voz, sem capacidade de reação, são mortos, despedaçados, vendidos, devorados. A autora evoca através de nossa simpathos um contato com eles, evidenciando cenas de morte, reclamando sobre a surdez e a cegueira coletivas, trazendo para o poema uma percepção do animal através da comoção, do sentimento, pois, como aponta Derrida 
(2003, p. 08), no texto “Ches cos’è la poesia?”, poema é aquilo “que ensina o coração, que inventa o coração, enfim aquilo que a palavra coração parece querer dizer e que na minha língua mal distingo da palavra coração".

Cabral, ao abordar os matadouros, obrigou seu leitor a lidar com uma presença incômoda, uma vez que a cegueira e a surdez voluntárias, adotadas socialmente, não podem ser mais usadas como justificativa para o desconhecimento desse cenário. Isso gera instabilidade nos poemas: a visão e a audição são solicitadas, literariamente, enquanto sentidos capazes de reconhecer a vida, a existência e a morte de seres diferentes do humano. O discurso racional é posto de lado, enquanto somos confrontados com o olhar vazio de uma cabeça animal decepada e pendurada em um açougue. Os eulíricos nos mostram o sangue, chamam atenção para a dor e o sofrimento de bois, direcionam nosso olhar e nossa audição para o ser vivo que, transformado em objeto, tem sua existência comercializada. Eles nos ofertam a oportunidade de questionar as práticas culturais que nos distanciam dos demais animais. Cabral nos apresenta, efetivamente, uma questão ética a qual, ao ser manifestada esteticamente através da literatura, visa tocar o sentimento humano, o coração que, como mencionou Derrida (2003), é o lugar da poesia, desvelando a cegueira e a surdez assumidas pela racionalidade frente aos animais, pois, como defende Dominique Lestel (2006, p. 41), “o animal não é um brinquedo nem um objeto, é antes de tudo uma presença e nisso se encontra suas especificidades. Ele encarna para o homem uma alteridade particular, portadora de sentido".

Em “Surdos e cegos" e "Açougue”, os animais são presenças viventes que, embora os eu-líricos lutem para que sejam percebidas em suas totalidades, têm seus corpos fragmentados, vendidos e devorados. Os poemas explicitam algo que incomoda, colocando em evidência construções sociais e históricas humanas que resultam em uma violência contra outros seres. O que está em questão não é o consumo de carne, mas sim a forma como o ser cuja carne é consumida é tratado. A violência, independente de sua origem, é um atentado contra uma outra vida. Sob esse prisma, esfumam-se as fronteiras de separação entre homens e animais, permitindo que associações como a criação e manutenção de matadouros e a ocorrência do Holocausto sejam possíveis, afinal, se desconsiderarmos as doutrinas e as teorias que nos colocam como superiores aos demais animais e os percebermos como uma alteridade, como um ser vivente que compartilha a existência conosco, o que diferenciará a violência cometida contra eles da cometida contra outros humanos? 


\section{CONSIDERAÇÕES FINAIS}

Georges Bataille (2015, p. 25), no livro Teoria da religião, defende que a animalidade se apresenta a nós como "um enigma bem embaraçoso", sendo impossível falar dela com precisão, a não ser de modo poético, pois “a poesia não descreve nada que não deslize para o incognoscível”. Se a poesia é capaz de abordar esse outro de nossa cultura, podemos entender os poemas de Astrid Cabral selecionados ("Surdos e cegos" e "Açougue") como uma oportunidade para discutirmos a posição concedida aos animais socialmente.

De acordo com o estudo desenvolvido, percebemos que alguns acontecimentos, ao longo de nossa história, foram capazes de alterar a forma como os animais eram tidos em nossa sociedade, criando um distanciamento entre eles e os humanos. Optei por destacar dois desses eventos: o cristianismo e a Modernidade. O primeiro associou os animais ao pecado, percebendo-os como negativos. Era necessário que o homem renegasse sua animalidade se quisesse alcançar a salvação. A segunda erigiu-se a partir do estabelecimento da razão como eixo central estruturador da sociedade. Os animais, desprovidos desse tipo de razão, foram considerados inferiores.

A rejeição e a inferioridade imputadas aos animais resultaram em formas de lidar com eles que poderiam ser consideradas perversas se fossem aplicadas aos homens. Um exemplo desse tipo de prática está na maneira como conduzimos a criação, a morte e o comércio de bovinos. Tratados como objetos, controlamos seus nascimentos, suas existências, determinamos suas mortes, fracionamos seus corpos e vendemos suas partes. Imersos em uma rotina que desconsidera a vida desses outros seres, os humanos assumem uma cegueira e uma surdez voluntárias.

Astrid Cabral, no entanto, usa seus poemas para romper com essa cegueira e essa surdez, aproximando homens e animais. A literatura, nesse caso, oferta ao leitor uma perspectiva que foge da razão filosófica ocidental, promovendo o conhecimento e a apreensão desse outro através não apenas da imaginação, mas também por meio do pathos, do simpathos. "Surdos e cegos" e "Açougue" oferecem, de forma crítica, a chance de reconhecermos nossas práticas sociais e repensarmos a violência que adotamos contra estes outros seres. 


\section{REFERÊNCIAS}

BATAILlE, G. Teoria da religião. Tradução de Fernando Scheibe. Belo Horizonte: Editora Autentica, 2015.

BERGER, J. Sobre o olhar. Tradução de Lya Luft. Barcelona: Gustavo Gili, 2003.

CABRAL, A. Jaula. Rio de Janeiro: Editora da Palavra, 2006.

CABRAL, A. Alameda. Organização Tenório Teles e estudo crítico por Antônio Paulo Graça. $2^{\mathrm{a}}$ ed. Manaus: Editora Valer, 1998.

COETZEE, J. M. A vida dos animais. Tradução de José Rubens Siqueira; introdução e organização de Amy Gutmann. São Paulo: Companhia das Letras, 2002.

DERRIDA, J. Che Cos’è la poesia? Tradução de Osvaldo Manuel Silvestre. Lisboa: Ângelus Novus, 2003.

DERRIDA, J. O animal que logo sou (A seguir). Tradução de Fábio Landa. São Paulo: Editora UNESP, 2002.

DESCARTES, R. Discurso do método. 2. ed. Tradução de Maria Ermantina Galvão. São Paulo: Martins Fontes, 2001.

GIORGI, G. A vida imprópria. Histórias de matadouros. In: MACIEL, M. E. (Org.) Pensar/ escrever o animal: Ensaios de zoopoética e biopolítica. Florianópolis: Editora da UFSC, 2011. p. 199-220

LESTEL, D. A animalidade, o humano e as "comunidades híbridas". In: MACIEL, M. E. (Org.) Pensar/ escrever o animal: Ensaios de zoopoética e biopolítica. Florianópolis: Editora da UFSC, 2011. p. $23-53$

MACIEL, M. E. Literatura e animalidade. Rio de Janeiro: Civilização Brasileira, 2016.

MONTAIGNE, M. de. Apologia de Raymond Sebond. In: . Os Ensaios: Livro II. Tradução de Rosemary Costhek Abílio. $2^{\mathrm{a}}$ ed. São Paulo: Martins Fontes, 2006. p. 157-407.

NIETZSCHE, F. Para além do bem e do mal: Prelúdio a uma filosofia do futuro. Tradução de Carlos Duarte e Anna Duarte. Coleção obra-prima de cada autor. São Paulo: Martin Claret, 2007a.

NIETZSCHE, F. O Anticristo: Maldição ao cristianismo; Ditirambos de Dionísio. Tradução, notas de posfácio de Paulo Cesár de Souza. São Paulo: Companhia das Letras, 2007 b. 
NIETZSCHE, F. Genealogia da moral: uma polêmica. Tradução, notas e posfácio de Paulo César de Souza. São Paulo: Companhia das Letras: 1998.

NUNES, B. O animal e o primitivo: Os outros de nossa cultura. In: MACIEL, M. E. (Org.) Pensar/ escrever o animal: Ensaios de zoopoética e biopolítica. Florianópolis: Editora da UFSC, 2011. p. 1322.

PAZ, O. Os filhos do barro: do romantismo à vanguarda. Tradução de Olga Savary. Rio de Janeiro: Nova Fronteira, 1984.

VOIGT, R. Astrid Cabral e a zoopoética. Voz da Literatura, Brasília-DF, v 1, n 1, p. 02-05, maio de 2018.

Recebido em 01/11/2018

Aceito em 16/01/2019 